DOI: 10.17707/AgricultForest.63.1.15

\author{
Milan BIBERDŽIĆ, Dragana LALEVIĆ, \\ Saša BARAĆ, Slaviša STOJKOVIĆ
}

\title{
PRODUCTIVE TRAITS OF TRITICALE DEPENDING ON SOWING RATE AND METEOROLOGICAL CONDITIONS IN TESTED YEARS
}

\section{SUMMARY}

The results of the examination of sowing density and meteorological conditions on productive traits of several genotypes of winter triticale are presented in this paper. The examination was conducted in the vicinity of Bijelo Polje, in the northern part of Montenegro in the period 2009-2012. The experiment, set in randomized block system with three replications included five varieties of winter triticale (Odysseus, Kg-20, Triumph, Rtanj and Tango) and two sowing rates (density) -600 and 800 germinated seeds per $\mathrm{m}^{-2}$. Common agronomical practices were used in the experiment, with the application of NPK fertilizer combinations 60:80:80. The following parameters were assessed: the number of grains per spike, 1000 grain weight, hectoliter weight and grain yields of triticale.

The results of the examination showed significant differences in reproductive traits of winter triticale, depending on the variety, sowing density and weather conditions in the years of research. Variety Tango had the highest average grain yield (5610.0 kg ha ${ }^{-1}$ ) and 1000 grain weight $(48.4 \mathrm{~g})$, while $\mathrm{Kg}-20$ had the lowest grain yield $\left(4465.6 \mathrm{~kg} \mathrm{ha}^{-1}\right)$. Variety Odysseus had the highest number of grains per spike (38.5), while the highest value of hectoliter weight was determined in variety Triumph. Significantly higher yields were achieved by applying higher sowing density in comparison to the standard application of lower sowing density. The results of the examination showed that the demonstrated differences of observed parameters of the varieties which were included in this examination are the results of the specificity of varieties, of agro technical practices and climatic conditions in the years of study.

Keywords: triticale, productive traits, sowing rate, meteorological conditions.

\section{INTRODUCTION}

Triticale (x Triticosecale Wittm.), as a new highly successful species of small grains, was created by crossing wheat and rye. It was designed with the idea to obtain a cereal, which combines good quality grain yield from wheat parent with tolerance to abiotic and biotic stress (Villegas et al., 2010). In recent years it has become increasingly important, both for our producers and in the

\footnotetext{
${ }^{1}$ Milan Biberdžić, Dragana Lalević (corresponding author: dragana.lalevic@gmail.com), Saša Barać, Slaviša Stojković University in Pristina, Faculty of Agriculture, Lešak, SERBIA

Paper presented at the $7^{\text {th }}$ International Scientific Agricultural Symposium "AGROSYM 2016".

Notes: The authors declare that they have no conflicts of interest. Authorship Form signed online.
} 
world. Ugarte et al. (2007), Estrada-Campuzano et al. (2008) reported that triticale is an interesting crop for unfavorable conditions where productivity of common crops is more or less limited. Also, triticale has high resistance to diseases and pests, and extremely good endurance to drought, acid soils and poor quality soils. New varieties of triticale are equal or superior to other cultures for grain yield, forage and biomass production for human food, animal feed and industrial applications (Nefir and Tabără, 2011).

Optimum sowing rate and advanced agricultural techniques, with a special turn to fertilizing, have a vital role in increasing yield and quality of plants. Seed rates above the optimum level impose nutrients, light, moisture stresses and hence adversely affect crop yield while seed rate below optimum level usually has low yield (Mut et al., 2005).

Joshi et al. (2002) reported that the desirable cultivars for high grain yield and quality traits need to express genetic potential in different environment of growing. High temperatures after anthesis have negative influence in grain filling. Díaz Zorita et al. (2001) reported that water deficiency during the period of anthesis is critical moment to normal cereal production, causing significant yield losses.

The aim of this study was to establish some productive traits of triticale in dependence of sowing rate, agroclimatic conditions of locality and varieties.

\section{MATERIALS AND METHODS}

This field experiment was carried out in the vicinity of Bijelo Polje (Montenegro), on $43^{\circ} 01^{\prime} 45^{\prime \prime}$ north latitude and $19^{\circ} 44^{\prime} 44^{\prime \prime}$ east longitude during the 2009-2012. The trial was performed in a randomized block system with three replications on alluvial type of soil and the size of experimental plot was $6 \mathrm{~m}^{2}$. The experiment included five varieties of winter triticale (Odysseus, $\mathrm{Kg}-20$, Triumph, Rtanj and Tango) and two sowing rates (density) - 600 and 800 germinated seeds per $\mathrm{m}^{-2}$. The fields were prepared with standard production practices for triticale varieties, with the application of NPK fertilizer combinations 60:80:80. The total amount of phosphorus and potassium were used in equal amounts $\left(80 \mathrm{~kg} \mathrm{ha}^{-1}\right)$ before the sowing period, while $1 / 3$ of nitrogen was used before the sowing period, and the rest of the planed amount was applied after hibernation at the tillering stage in early spring. Sowing was carried out by manual method in optimal sowing date (October).The harvest was conducted, also, manually at the stage of full maturity, where the number of grains per spike, 1000 grain weight were measured, as well as the hectoliter weight, and the grain yield was corrected for $14 \%$ moisture. The average results of number of grain per spike, yield of dry grain, hectoliter weight, 1000 grain weight are presented in this paper, for the analyzed period of three years.

The obtained results were statistically processed using method of variance analysis, whereby the significance of average treatments was tested with LSD test, with significance threshold of 1 and $5 \%$. 


\section{RESULTS AND DISCUSSION}

The soil on which the experiment was carried out belongs to the alluvial type of soil. It is weakly calcareous, with total content of carbonate being 2.4$2.44 \%$. The soil is quite humic: $3.35-3.96 \%$ by low content of available phosphorus $5.12-4.24 \mathrm{mg} / 100 \mathrm{~g}$ soil) and potassium content $(7.5-3.8 \mathrm{mg} / 100 \mathrm{~g}$ soil).

Meteorological conditions, especially the precipitation and the temperature, largely determine the success of the production of winter triticale and other small grains.

The data in Table 2. indicate that the years in which this research was conducted varied in climate conditions. In the growing season 2009/10 there were $881 \mathrm{~mm}$ of rainfall which is $116 \mathrm{~mm}$ or $329 \mathrm{~mm}$ more than in the second and third year of the research.

Table 1. Meteorological data for Bijelo Polje

\begin{tabular}{|c|c|c|c|c|c|c|c|c|c|c|c|}
\hline \multirow{2}{*}{ Year } & \multicolumn{10}{|c|}{ Months } & \multirow{2}{*}{ Sum } \\
\cline { 2 - 10 } & X & XI & XII & I & II & III & IV & V & VI & VII & \\
\hline \multicolumn{10}{|c|}{ Monthly rainfall (mm) } \\
\hline $\mathbf{2 0 0 9 - 1 0}$ & 135 & 94 & 94 & 101 & 80 & 70 & 78 & 80 & 63 & 86 & $\mathbf{8 8 1}$ \\
\hline $\mathbf{2 0 1 0 - 1 1}$ & 65 & 131 & 147 & 36 & 76 & 31 & 46 & 121 & 33 & 79 & $\mathbf{7 6 5}$ \\
\hline $\mathbf{2 0 1 1 - 1 2}$ & 36 & 7 & 55 & 79 & 183 & 57 & 47 & 46 & 34 & 8 & $\mathbf{5 5 2}$ \\
\hline \multicolumn{10}{|c|}{ Average monthly temperatures $\left({ }^{\circ} \mathbf{C}\right)$} \\
\hline $\mathbf{2 0 0 9 - 1 0}$ & 9.77 & 5.95 & 4.06 & 1.31 & 2.4 & 6.39 & 10.93 & 15 & 18.11 & 20.95 & $\mathbf{9 . 5}$ \\
\hline $\mathbf{2 0 1 0 - 1 1}$ & 10.12 & 8.54 & 2.05 & -0.65 & 0.94 & 6.03 & 10.54 & 14.5 & 18.9 & 21.23 & $\mathbf{9 . 2}$ \\
\hline $\mathbf{2 0 1 1 - 1 2}$ & 9.3 & 3.25 & 2.17 & -1.72 & -3.52 & 5.96 & 10.8 & 15.02 & 20.67 & 24.63 & $\mathbf{8 . 7}$ \\
\hline
\end{tabular}

Average temperatures were similar during the first $\left(9.5^{\circ} \mathrm{C}\right)$ and the second $\left(9.2^{\circ} \mathrm{C}\right)$ research years. In $2011 / 12$, average temperature was lower than in the previos both years. From the data in the Table 2 it can be noted that conditions for germination and autumn plant development were considerably favorable during the first two years compared to the third year of research.

Also, the amount of rainfall in the period from April to June in the first year of research was higher compared to the other two years of research. Considering that the amount of rainfall and temperature in these months are extremely important for the development of small grains, the first year of research can be characterized as the most optimal in terms of weather conditions for growing triticale in this area.

Productive characteristics directly influence the forming of yield. Especially important is the advantage of agro-climatic factors. Table 3. provides an overview of some productive characteristics of triticale depending on variety and meteorological conditions in tested years.

The number of grains per spike is one of the most important components of yield and with the 1000 kernels weight dictates grain yield per spike (Milovanović et al., 2014). 
Table 2. Number of grains per spike in dependence of variety, sowing rate and agroclimatic conditions

\begin{tabular}{|c|c|c|c|c|c|c|c|c|c|c|}
\hline \multirow{4}{*}{\multicolumn{2}{|c|}{ Variety }} & \multicolumn{9}{|c|}{ Number of grains per spike } \\
\hline & & \multicolumn{9}{|c|}{ Year } \\
\hline & & \multicolumn{2}{|c|}{$2009 / 10$} & \multirow{2}{*}{ Average } & \multicolumn{2}{|c|}{$2010 / 11$} & \multirow{2}{*}{ Average } & \multicolumn{2}{|c|}{ 2011/12 } & \multirow{2}{*}{ Average } \\
\hline & & $\mathbf{G}_{1}$ & $\mathbf{G}_{2}$ & & $\mathbf{G}_{1}$ & $\mathbf{G}_{2}$ & & $\mathbf{G}_{1}$ & $\mathbf{G}_{2}$ & \\
\hline \multicolumn{2}{|c|}{ Odisey } & 47.0 & 45.0 & 46.0 & 33.3 & 31.7 & 32.5 & 38.0 & 36.3 & 37.1 \\
\hline \multicolumn{2}{|c|}{$\mathrm{Kg}-20$} & 33.7 & 31.7 & 32.7 & 34.6 & 31.7 & 33.1 & 29.1 & 28.2 & 28.6 \\
\hline \multicolumn{2}{|c|}{ Triumph } & 28.8 & 27.5 & 28.1 & 27.6 & 26.4 & 27.0 & 28.1 & 25.9 & 27.0 \\
\hline \multicolumn{2}{|c|}{ Rtanj } & 33.0 & 32.0 & 32.5 & 34.1 & 33.6 & 33.8 & 33.2 & 31.8 & 32.5 \\
\hline \multicolumn{2}{|c|}{ Tango } & 34.3 & 33.7 & 34.0 & 33.9 & 31.1 & 32.5 & 30.8 & 30.2 & 30.5 \\
\hline \multirow{2}{*}{\multicolumn{2}{|c|}{ Average }} & 35.4 & 33.9 & 34.6 & 32.7 & 30.9 & 31.8 & 31.8 & 30.5 & 31.1 \\
\hline & & A & B & AB & $\mathbf{A}$ & B & AB & $\mathbf{A}$ & B & $\mathbf{A B}$ \\
\hline \multirow{2}{*}{ LSD } & 0.05 & 0.903 & 0.571 & 1.277 & 1.148 & 0.726 & 1.623 & 1.097 & 0.694 & 1.551 \\
\hline & 0.01 & 1.281 & 0.810 & 1.811 & 1.638 & 1.029 & 2.303 & 1.555 & 0.984 & 2.199 \\
\hline
\end{tabular}

$* \mathrm{G}_{1}$ - sowing rate (600 germinated seeds per $\left.\mathrm{m}^{2}\right)$

$\mathrm{G}_{2}$ - sowing rate $\left(800\right.$ germinated seeds per $\mathrm{m}^{2}$ )

The highest average number of grains per spike (46.0) was recorded in variety Odysseus in the first year of research. With the application of the lower sowing rate a significantly higher number of grains per spike was achieved compared with the application of the sowing rate of 800 germinated seeds per $\mathrm{m}^{2}$ in all tested varieties in all three years of research. Our results are in agreement with the results of Bokan and Malesevic (2004), which indicate a decrease in the number of grains per spike with the increase of sowing rate.

The1000 grain weight is one of the properties that directly affect the grain yield. Our results showed statistically significant differences in the 1000 grain weight between the first and the other two years of study. Our results are in agreement with the results of Jelic et al. (2002) who point out that the 1000 grain weight is a varietal characteristics, but also with Djekic et al. (2010) who found that the 1000 grain weight varies considerably depending on the weather conditions in each year of study. Also the data show that there is a statistically significant difference in the values of the 1000 grain weight depending on the sowing rate. Miric et al. (2007) reported that the 1000 grain weight decreases with the increasing sowing rate, or planting density, but it is very specific to each variety, which is confirmed by our results.

Hectoliter weight is also an important indicator of the technological value of seed. The obtained results are in agreement with the literature data, which point out that beside the variety and nutrition, meteorological conditions show significant influence on hectoliter weight. The highest hectoliter weight, in the three-year average, had the variety Triumph $(72.99 \mathrm{~kg})$, which is in agreement with the results of Milovanovic et al. (2004), who point out that the mentioned variety, beside the high and stable yield is characterized by good quality parameters. 
Table 3. Mass of 1000 grain in dependence of variety, sowing rate and agro-climatic conditions

\begin{tabular}{|c|c|c|c|c|c|c|c|c|c|c|}
\hline \multirow{4}{*}{\multicolumn{2}{|c|}{ Variety }} & \multicolumn{9}{|c|}{ Mass of 1000 grain $(\mathrm{g})$} \\
\hline & & \multicolumn{9}{|c|}{ Year } \\
\hline & & \multicolumn{2}{|c|}{$2009 / 10$} & \multirow[b]{2}{*}{ Average } & \multicolumn{2}{|c|}{$2010 / 11$} & \multirow[b]{2}{*}{ Average } & \multicolumn{2}{|c|}{$2011 / 12$} & \multirow[b]{2}{*}{ Average } \\
\hline & & $\mathbf{G}_{1}$ & $\mathbf{G}_{2}$ & & $\mathbf{G}_{1}$ & $\mathbf{G}_{2}$ & & $\mathbf{G}_{1}$ & $\mathbf{G}_{2}$ & \\
\hline \multicolumn{2}{|c|}{ Odisey } & 45.1 & 44.0 & 44.6 & 40.5 & 40.2 & 40.3 & 42.0 & 40.3 & 41.2 \\
\hline \multicolumn{2}{|c|}{$\mathrm{Kg}-20$} & 36.2 & 35.2 & 35.7 & 36.3 & 35.7 & 36.0 & 33.3 & 31.7 & 32.5 \\
\hline \multicolumn{2}{|c|}{ Triumph } & 48.5 & 47.8 & 48.1 & 42.0 & 40.7 & 41.3 & 42.2 & 41.8 & 42.0 \\
\hline \multicolumn{2}{|c|}{ Rtanj } & 46.3 & 45.8 & 46.1 & 47.5 & 46.2 & 46.9 & 45.7 & 44.6 & 45.2 \\
\hline \multicolumn{2}{|c|}{ Tango } & 49.2 & 48.5 & 48.8 & 49.7 & 48.0 & 48.8 & 48.0 & 46.8 & 47.4 \\
\hline \multirow{2}{*}{\multicolumn{2}{|c|}{ Average }} & 45.1 & 44.3 & 44.7 & 43.2 & 42.2 & 42.7 & 42.2 & 41.0 & 41.6 \\
\hline & & $\mathbf{A}$ & B & AB & $\mathbf{A}$ & B & $\mathbf{A B}$ & $\mathbf{A}$ & $\mathbf{B}$ & $\mathbf{A B}$ \\
\hline \multirow{2}{*}{ LSD } & 0.05 & 0.689 & 0.436 & 0.975 & 0.899 & 0.569 & 1.271 & 0.607 & 0.384 & 0.859 \\
\hline & 0.01 & 0.978 & 0.619 & 1.383 & 1.264 & 0.796 & 1.802 & 0.862 & 0.545 & 1.218 \\
\hline
\end{tabular}

$* \mathrm{G}_{1}$ - sowing rate $\left(600\right.$ germinated seeds per $\left.\mathrm{m}^{2}\right)$

$\mathrm{G}_{2}$ - sowing rate $\left(800\right.$ germinated seeds per $\left.\mathrm{m}^{2}\right)$

Table 4. Hectoliter weight in dependence of variety, sowing rate and agro-climatic conditions

\begin{tabular}{|c|c|c|c|c|c|c|c|c|c|c|}
\hline \multirow{4}{*}{\multicolumn{2}{|c|}{ Variety }} & \multicolumn{9}{|c|}{ Hectoliter weight (kg) } \\
\hline & & \multicolumn{9}{|c|}{ Year } \\
\hline & & \multicolumn{2}{|c|}{$2009 / 10$} & \multirow[b]{2}{*}{ Average } & \multicolumn{2}{|c|}{$2010 / 11$} & \multirow[b]{2}{*}{ Average } & \multicolumn{2}{|c|}{ 2011/12 } & \multirow[b]{2}{*}{ Average } \\
\hline & & $\mathbf{G}_{1}$ & $\mathbf{G}_{2}$ & & $\mathbf{G}_{1}$ & $\mathbf{G}_{2}$ & & $\mathbf{G}_{1}$ & $\mathbf{G}_{2}$ & \\
\hline \multicolumn{2}{|c|}{ Odisey } & 73.9 & 76.2 & 75.1 & 67.0 & 67.6 & 67.3 & 67.1 & 70.8 & 68.9 \\
\hline \multicolumn{2}{|c|}{$\mathrm{Kg}-20$} & 61.8 & 67.4 & 64.6 & 61.2 & 63.2 & 62.2 & 59.6 & 69.5 & 64.5 \\
\hline \multicolumn{2}{|c|}{ Triumph } & 73.4 & 75.7 & 74.5 & 69.5 & 70.4 & 69.9 & 66.4 & 69.5 & 67.9 \\
\hline \multicolumn{2}{|c|}{ Rtanj } & 67.9 & 69.1 & 68.4 & 65.6 & 67.8 & 66.7 & 63.1 & 64.9 & 64.0 \\
\hline \multirow{3}{*}{\multicolumn{2}{|c|}{$\begin{array}{c}\text { Tango } \\
\text { Average }\end{array}$}} & 65.9 & 72.7 & 69.3 & 66.4 & 69.6 & 68.0 & 64.5 & 65.3 & 64.9 \\
\hline & & 68.6 & 72.2 & 70.4 & 65.9 & 67.7 & 66.8 & 64.1 & 68.0 & 66.1 \\
\hline & & $\mathbf{A}$ & B & AB & A & B & AB & A & B & AB \\
\hline & 0.05 & 0.697 & 0.441 & 0.985 & 0.579 & 0.366 & 0.819 & 0.800 & 0.506 & 1.312 \\
\hline & 0.01 & 0.988 & 0.625 & 1.394 & 0.821 & 0.519 & 1.161 & 1.123 & 0.725 & 1.605 \\
\hline
\end{tabular}

$* \mathrm{G}_{1}$ - sowing rate $\left(600\right.$ germinated seeds per $\left.\mathrm{m}^{2}\right)$

$\mathrm{G}_{2}$ - sowing rate $\left(800\right.$ germinated seeds per $\left.\mathrm{m}^{2}\right)$

Also, the results showed that in the third year, which was the least favorable according to the climate characteristics, the lowest average value of the hectoliter weight was recorded. The influence of meteorological factors on the value of the hectoliter weight was confirmed earlier by other authors in their researches (Lalevic et al., 2012).

The grain yield of the tested genotypes of triticale showed considerable variation depending on the amount of seed used for planting and the weather conditions in the years of research. 
In all three years of research, the application of the higher sowing rate caused a significantly higher yield in all tested varieties compared to the application of the lower sowing rate. The highest average yield, in all three years of research, of $6135.5 \mathrm{~kg} \mathrm{ha}^{-1}$ was obtained with variety Tango at the highest sowing rate $\left(800\right.$ germinated seeds per $\left.\mathrm{m}^{2}\right)$. The lowest yield, in the three-year average, was obtained with the variety $\mathrm{Kg}-20$ with the application of both sowing rates.

During the research, the yield variation was noticed, which was the result of different climatic factors (precipitation and temperature). The highest grain yield was achieved in the first year, which in terms of quantity and distribution of rainfall was the best.

The most unfavorable weather conditions for the cultivation of triticale were in the third year of research, which was reflected on the yield. Significant yield variation depending on the conditions and sowing rates were pointed out previously by other authors (Pecio, 2010; Biberdzic et al., 2013).

Table 6.Grain yield in dependence of variety, sowing rate and agro-climatic conditions

\begin{tabular}{|c|c|c|c|c|c|c|c|c|c|}
\hline \multirow{4}{*}{ Variety } & \multicolumn{9}{|c|}{ Number of grains per spike } \\
\hline & \multicolumn{9}{|c|}{ Year } \\
\hline & \multicolumn{2}{|c|}{$2009 / 10$} & \multirow{2}{*}{ Average } & \multicolumn{2}{|c|}{ 2010/11 } & \multirow{2}{*}{ Average } & \multicolumn{2}{|c|}{ 2011/12 } & \multirow[b]{2}{*}{ Average } \\
\hline & G1 & G2 & & G1 & G2 & & G1 & G2 & \\
\hline Odisey & 47.0 & 45.0 & 46.0 & 33.3 & 31.7 & 32.5 & 38.0 & 36.3 & 37.1 \\
\hline $\mathrm{Kg}-20$ & 33.7 & 31.7 & 32.7 & 34.6 & 31.7 & 33.1 & 29.1 & 28.2 & 28.6 \\
\hline Triumph & 28.8 & 27.5 & 28.1 & 27.6 & 26.4 & 27.0 & 28.1 & 25.9 & 27.0 \\
\hline Rtanj & 33.0 & 32.0 & 32.5 & 34.1 & 33.6 & 33.8 & 33.2 & 31.8 & 32.5 \\
\hline Tango & 34.3 & 33.7 & 34.0 & 33.9 & 31.1 & 32.5 & 30.8 & 30.2 & 30.5 \\
\hline \multirow[t]{2}{*}{ Average } & 35.4 & 33.9 & 34.6 & 32.7 & 30.9 & 31.8 & 31.8 & 30.5 & 31.1 \\
\hline & $\mathbf{A}$ & B & $\mathbf{A B}$ & $\mathbf{A}$ & B & $\mathbf{A B}$ & $\mathbf{A}$ & B & $\mathbf{A B}$ \\
\hline \multirow{2}{*}{\begin{tabular}{l|l} 
LSD & 0.05 \\
\cline { 2 - 2 } & 0.01
\end{tabular}} & 0.903 & 0.571 & 1.277 & 1.148 & 0.726 & 1.623 & 1.097 & 0.694 & 1.551 \\
\hline & 1.281 & 0.810 & 1.811 & 1.638 & 1.029 & 2.303 & 1.555 & 0.984 & 2.199 \\
\hline
\end{tabular}

* $\mathrm{G}_{1}$ - sowing rate $\left(600\right.$ germinated seeds per $\left.\mathrm{m}^{2}\right)$

$\mathrm{G}_{2}$ - sowing rate $\left(800\right.$ germinated seeds per $\left.\mathrm{m}^{2}\right)$

\section{CONCLUSIONS}

Based on the studying the influence of sowing rate and meteorological conditions on productive traits of triticale, it can be concluded that:

All tested varieties, in all three years of research, achieved significantly higher yield with the application of the higher sowing rate compared to the application of the lower sowing rate;

The average yield of tested varieties of triticale was highest in the first and lowest in the third year of the study;

On average, the highest number of grains per spike and the 1000 grain weight of the tested winter triticale varieties, was achieved with the application of the lower sowing rate in the first year of research; 
Variety Tango achieved the highest yield in the first year of research with the application of the higher sowing rate, while the lowest yield was recorded at variety $\mathrm{Kg}-20$ in the third year of research with the application of the lower sowing rate;

The highest hectoliter weight was achieved at variety Triumph $(75.7 \mathrm{~kg})$ in the first year of research with the application of the higher sowing rate;

The differences of the observed parameters at the tested varieties are the result of varietal specifics, the applied agro technical practices and the climate conditions in the years of research.

\section{ACKNOWLEDGMENT}

The study published in this paper is a part of the project "The development of new technologies of small grains cultivation on acid soils using contemporary biotechnology" financed by the Ministry of Education and Science of the Republic of Serbia, grant No TR-31054.

\section{REFERENCES}

Biberdžić, M., Jelić, M., Knežević, B., Barać, S., Maksimović, G., Lalević, D. (2013): The effect of climatic conditions and variety on some morphological and productivity characteristics of triticale. Research Journal of Agricultural Science, 45 (3), 24-29.

Bokan, N., Malešević, M. (2004): The planting effect on wheat yield structure. Acta Agriculturae Serbica, Vol. Ix, 18, p. 65-79.

Díaz Zorita, M., Fernández-Canigia, M.V., Grosso, G.A. (2001): Applications of foliar fertilizers on yield and quality in sunflower (Helianthus annuus L.). Pacistan J. Biol. Sci. 7: 384-388.

Djekić, V., Milovanović, M., Staletić, M., Perišić, V. (2010): Ispitivanje komponenti prinosa kragujevačkih sorti ozimog tritikalea (Investigation of yield components Kragujevac varieties winter triticale). Zbornik naučnih radova instituta PKB Agroekonomik 16, 1-2, 35-41.

Estrada-Campuzano, G., Miralles, D.J., Slafer, G.A. (2008): Genotypic variability and response to water stress of pre- and post-anthesis phases in triticale. European Journal of Agronomy, 28 (3): 171-177.

Jelić, M., Stojanović, J., Stojanović, S., Živanović, S. (2002): Optimalna tehnologija proizvodnje kragujevačkih sorti strnih žita (The optimal production technology of Kragujevac varieties of small grains). Agroinovacija br. 3, 163-171.

Joshi, S. K., Sharma, S. N., Singhania, Sain, R.S. (2002): Genetic analysis of quantitative and quality traits under varying environmental conditions in bread wheat. Wheat Information Service, 95: 5-10.

Lalević, D., Biberdžić, M., Jelić, M., Barać, S. (2012): Some characteristics of triticale cultivated in rural areas, Agriculture \& Forestry, Vol. 58 Issue 2, p27-34. 8p.

Milovanović, M., Perišić, V., Staletić, M. (2004): New cultivar of winter triticale Triumph. Book of Abstracts of the III Congress of Serbian, Subotica, p. 168.

Milovanovic, M., Perishic, V., Staletic, M., Djekic, V., Nikolic, O., Prodanovic, S., Lukovic, K. (2014): Diallel analysis of grain number per spike in Triticale, Bulgarian Journal of Agricultural Science, Agricultural Academy 20 (No 5) 2014, 1109-1115. 
Mirić, M., Selaković, D., Jovin, P., Hojka, Z., Filipović, M. (2007): Masa 1000 semena u teoriji i praksi, Selekcija i semenarstvo, Plantbreeding and seedproduction, Vol. XIII, No. 3-4 (2007), str. 49-58, Novi Sad.

Mut, Z., Sezer, I., Gulumser, A. (2005): Effect of different sowing rates and nitrogen levels on grain yield, yield components and some quality traits of triticale, Asian Journal of Plant Sciences, 4 (5), 533-539.

Nefir, P., Tabără, V. (2011): Effect on products from variety fertilization and triticale (Triticosecale Wittmack) in the experimental field from Răcăşdia Caras-Severin country. Res. J. Agric. Sci. 43(4): 133-137.

Pecio, A. (2010): Productivity of triticale affected by nitrogen fertilization and weather conditions. Fertilizer and fertilization, 40: 101-116.

Villegas, D., Casadesus, J., Atienza, S., Martos, V., Maalouf, F., Karam, F., Aranjuelo, I., Nogues, S. (2010): Tritodeum, wheat and triticale yield components under multilocal mediterranean drought conditions. Field. Crops Research, 100: 240-248.

Ugarte, C., Calderini, D. F., Slafer, G. A. (2007): Grain weight and grain number responsiveness to pre-anthesis temperature in wheat, barley and triticale. Field Crops Research, 116: 68-74. 